\title{
Regionalna obilježja poljoprivredne proizvodnje Kontinentalne Hrvatske
}

\section{Sažetak}

Cilj rada bio je dati pregled odabranih socio-ekonomskih i proizvodnih pokazatelja na području Kontinentalne Hrvatske te ih usporediti s državnim prosjekom u razdoblju od 2009. do 2018. godine. Dobna struktura nositelja OPG-ova je povoljnija u Kontinentalnoj Hrvatskoj (veći udio mlađih od 41 godine; manji udio starijih od 65 godina) u odnosu na državni prosjek dok je obrazovna lošija (koeficijent obrazovanosti 1,38). Broj zaposlenih u poljoprivredi je u padu, dok vanjskotrgovinska razmjena poljoprivrede, šumarstva $i$ ribarstva bilježi rast vrijednosti u promatranom razdoblju. Korištene poljoprivredne površine su se povećale u promatranom razdoblju isključivo zbog povećanja površina pod trajnim travnjacima što se negativno odrazilo na bruto dodanu vrijednost poljoprivrede koja ima negativan trend u promatranom razdoblju. Navedeno je i posljedica smanjenja stočarske proizvodnje, posebice govedarstva i svinjogojstva. Hrvatskoj poljoprivredi potrebna je generacijska obnova koja će ujedno pridonijeti poboljšanju obrazovne strukture i veća usmjerenost sredstava u stočarsku proizvodnju koja stvara veću dodanu vrijednost.

Ključne riječi: Kontinentalna Hrvatska, poljoprivreda, proizvodni pokazatelji, RH, socio-ekonomska obilježja

\section{Uvod}

Udio poljoprivrede, šumarstva i ribarstva RH u ukupnom bruto domaćem proizvodu (BDP) za razdoblje 2000./2017. godine iznosi oko 4\%, dok je u bruto dodanoj vrijednosti (BDV) oko 5\%. Sama poljoprivreda u BDP-u i u BDV- u sudjeluje s oko 3\% (Grgić i sur., 2019).

Republika Hrvatska je 1. siječnja 2013. godine prema NUTS klasifikaciji ${ }^{3}$ podijeljena na dvije NUTS 2 regije, Kontinentalnu i Jadransku, a razlog podjele je da se što učinkovitije iskoriste sredstva iz EU fondova. Kontinentalna Hrvatska (KH) tom podjelom obuhvaća 13 županija i Grad Zagreb, ukupne površine $31.889 \mathrm{~km}^{2}$.

U Kontinentalnoj Hrvatskoj se, prema podacima EUROSTAT-a, 2016. godine za poljoprivrednu proizvodnju koristilo 1.095 .430 ha zemljišta. Na tim površinama najviše su se uzgajale ratarske kulture kao što su pšenica, ječam, kukuruz i sl., stoga je ratarstvo glavna poljoprivredna djelatnost Kontinentalne Hrvatske. U radu će se prikazati socijalno-ekonomska i proizvodna obilježja poljoprivrede Kontinentalne Hrvatske u razdoblju od 2009. do 2018. godine. Od socijalno-ekonomskih pokazatelja prikazat će se dobna i obrazovna struktura nositelja obiteljskih poljoprivrednih gospodarstava (OPG), zaposlenost u poljoprivredi, vanjskotrgovinska razmjena te bruto dodana vrijednost u sektoru poljoprivrede, šumarstva i ribarstva, dok će se od proizvodnih pokazatelja prikazati korištene poljoprivredne površine po kategorijama, biljna i životinjska proizvodnja, te udio ekološke proizvodnje u ukupnoj poljoprivrednoj proizvodnji Kontinentalne Hrvatske.

Dr. sc. Mateja Jež Rogelj, dr. sc. Magdalena ZrakićSušac, doc. dr. sc. Ornella Mikuš, Sveučilište u Zagrebu Agronomski fakultet, Svetošimunska cesta 25, 10000 Zagreb, Hrvatska

Petar Glavota, bacc. ing. agr., Student na Agronomskom fakultetu Sveučilišta u Zagrebu, MS studij Agrobiznis i ruralni razvitak Autor za korespondenciju:mzrakic@agr.hr

NUTS regije u Republici Hrvatskoj ili NKPJS-Nacionalna klasifi acija prostornih jedinica za statistiku Državnog zavoda za statistiku Republike Hrvatske odnosi se na teritorijalnu podjelu Republike Hrvatske za statističke potrebe, prema europskoj,Nomenklaturi prostornih jedinica za statistiku“ (NUTS- fr: Nomenclature des unités territoriales statistiques) 
Regija Kontinentalna Hrvatska odabrana je jer se tamo nalazi većina korištenog poljoprivrednog zemljišta $(69,48 \%)$, odvija većina poljoprivredne proizvodnje i stvara gotovo $70 \%$ bruto dodane vrijednosti hrvatske poljoprivrede.

\section{Materijali i metode}

U radu je korištena metoda analize sadržaja sekundarnih izvora podataka, metoda trenda i metoda baznih indeksa. Bazna godina za izračun baznih indeksa je 2013., kao prva godina članstva u Europskoj uniji kada su nastupile važne promjene u vanjskotrgovinskoj razmjeni za domaće tržište (izlazak iz CEFTE i trgovanja unutar EU bez carina). Za prikaz obrazovanosti nositelja obiteljskih poljoprivrednih gospodarstva korišten je koeficijent obrazovanosti odnosno omjer broja nositelja sa završenim fakultetskim obrazovanjem, višom i srednjom školom, i onih bez škole, sa završenih nekoliko razreda osnovne škole te sa završenom osnovnom školom.

Glavni izvori podataka su EUROSTAT, Državni zavod za statistiku (DZS), Ekonomski računi u poljoprivredi te podatci Agencije za plaćanja u poljoprivredi, ribarstvu i ruralnom razvoju.

\section{Rezultati i rasprava}

Socijalno-ekonomska obilježja

Grafikon 1 prikazuje dobnu strukturu nositelja obiteljskih poljoprivrednih gospodarstava. Vidljivo je da je ona povoljnija u Kontinentalnoj Hrvatskoj u odnosu na državni prosjek (veći udio mlađih od 41 godine $-13,27 \%$ i manji udio starijih od 65 godina $-35,67 \%$ ). Za usporedbu, u 2013. godini je u EU bilo $6 \%$ poljoprivrednika mlađih od 35 godina i $31 \%$ starijih od 65 godina (Augère-Granier, 2017).

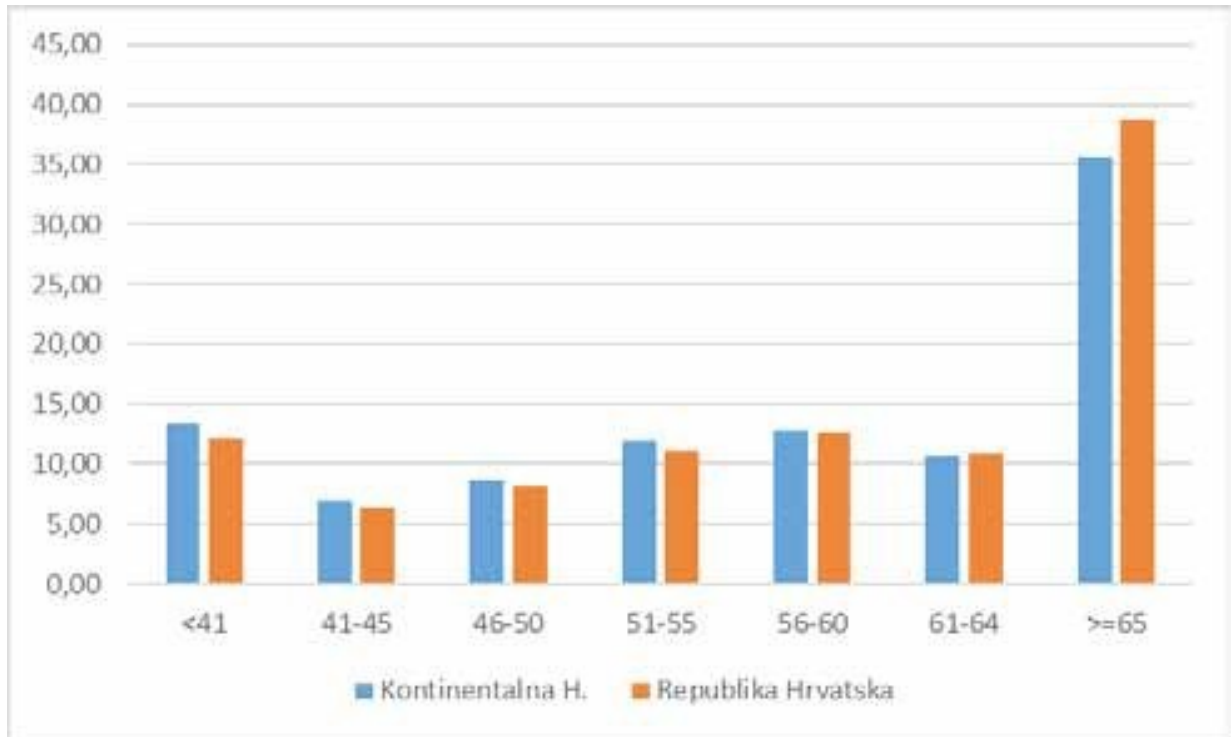

Grafikon 1. Udio nositelja OPG-ova prema dobi nositelja gospodarstva u Hrvatskoj u 2018. godini

Graph 1. Share of Family farm holders by age of the holder in Croatia in 2018

Izvor: Izračun autora prema podatcima iz Upisnika poljoprivrednika/ Source: Author's calculation according to the data from the Register of farmers 
Osim dobne, nepovoljna je i obrazovna struktura hrvatskih poljoprivrednika općenito, a posebice u Kontinentalnoj Hrvatskoj (grafikon 2). Jež Rogelj i sur. (2019) smatraju kako trenutna dobna i obrazovna struktura hrvatskih poljoprivrednika ukazuje na socio-demografske poteškoće u uključivanju inovacija u njihovu poslovnu praksu obzirom da inovacije lakše i brže prihvaćaju mlađi i obrazovaniji poljoprivrednici koji su još uvijek u Hrvatskoj u manjini premda se radi na generacijskoj obnovi sela kroz Program ruralnog razvoja. Nedostatak mladih poljoprivrednika evidentan je na razini cijele EU što za sobom povlači i lošiju obrazovnu strukturu poljoprivrednika. Augère-Granier (2017) navodi kako je kod poljoprivrednika mlađih od 35 godina najveći udio onih sa završenom višom poljoprivrednom školom, dok kod starijih od 65 godina prevladavaju oni koji imaju samo praktično poljoprivredno iskustvo.

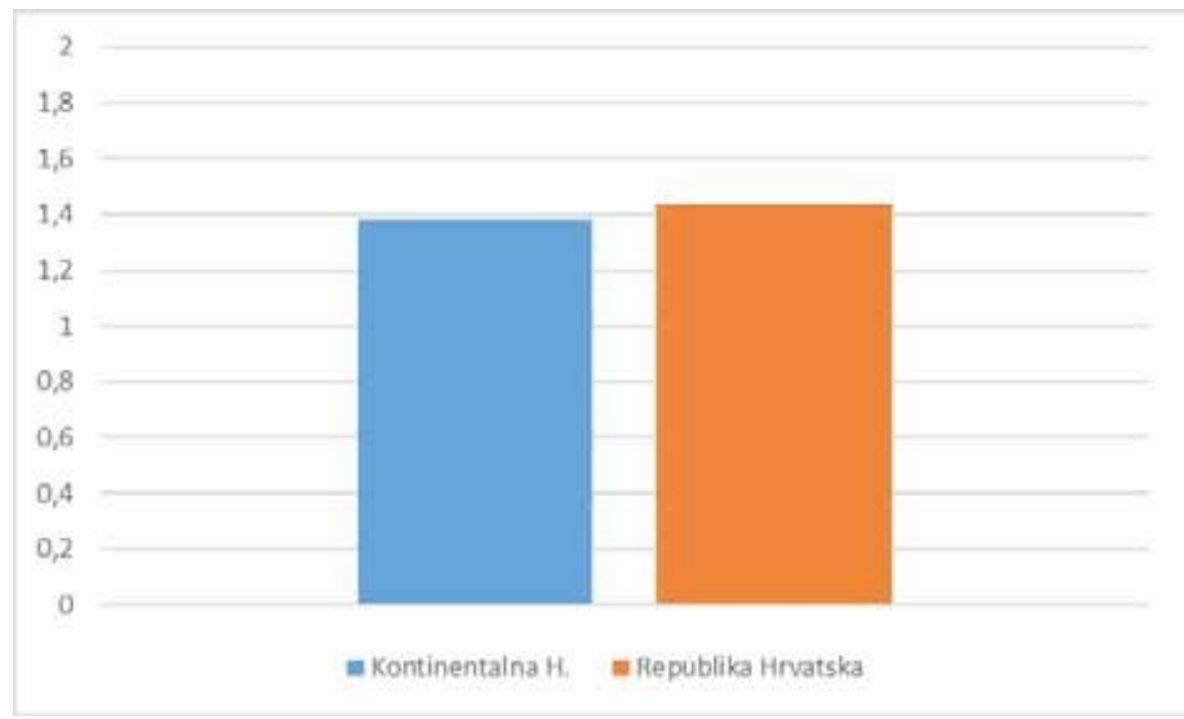

Grafikon 2. Koeficijent obrazovanosti nositelja OPG-ova

Graph 2. Family farm holder's Coefficient of education

Izvor: Izračun autora prema podatcima iz Upisnika poljoprivrednika (2018.)/ Source: Author's calculation according to the data from the Register of farmers (2018)

Na grafikonu 3 prikazano je kretanje broja zaposlenih u poljoprivredi Kontinentalne Hrvatske i na razini Republike Hrvatske u razdoblju od 2009. do 2018. godine. Iz prikaza je vidljiv negativan trend broja zaposlenih kako na razini Hrvatske tako i u Kontinentalnoj Hrvatskoj. Najviše zaposlenih u poljoprivredi bilo je 2012. godine kada je u RH bilo 25.667 zaposlenih, a u Kontinentalnoj Hrvatskoj njih 20.038. Mogući uzroci pada broja zaposlenih u poljoprivredi su deagrarizacija kao i iseljavanje stanovništva u inozemstvo. Stipić (2018) navodi kako je iseljavanje mladih glavna razvojna prepreka s kojom se suočavaju mnoga sela u Hrvatskoj jer se njihovom migracijom gubi radna snaga i gase obiteljska poljoprivredna gospodarstva.

Vanjskotrgovinska bilanca poljoprivrede, šumarstva i ribarstva Republike Hrvatske kao i Kontinentalne Hrvatske vrlo je varijabilna u razdoblju od 2013. do 2018. godine (grafikon 4). Najveća pokrivenost uvoza izvozom na razini Hrvatske bila je 2015., a u Kontinentalnoj Hrvatskoj 2018. godine (tablica 1). Negativna vanjskotrgovinska bilanca za Kontinentalnu Hrvatsku zabilježena je 2013. godine, dok je u istoj godini na razini cijele države ona bila nešto iznad nule i to zahvaljujući pozitivnoj vanjskotrgovinskoj bilanci Jadranske Hrvatske. 


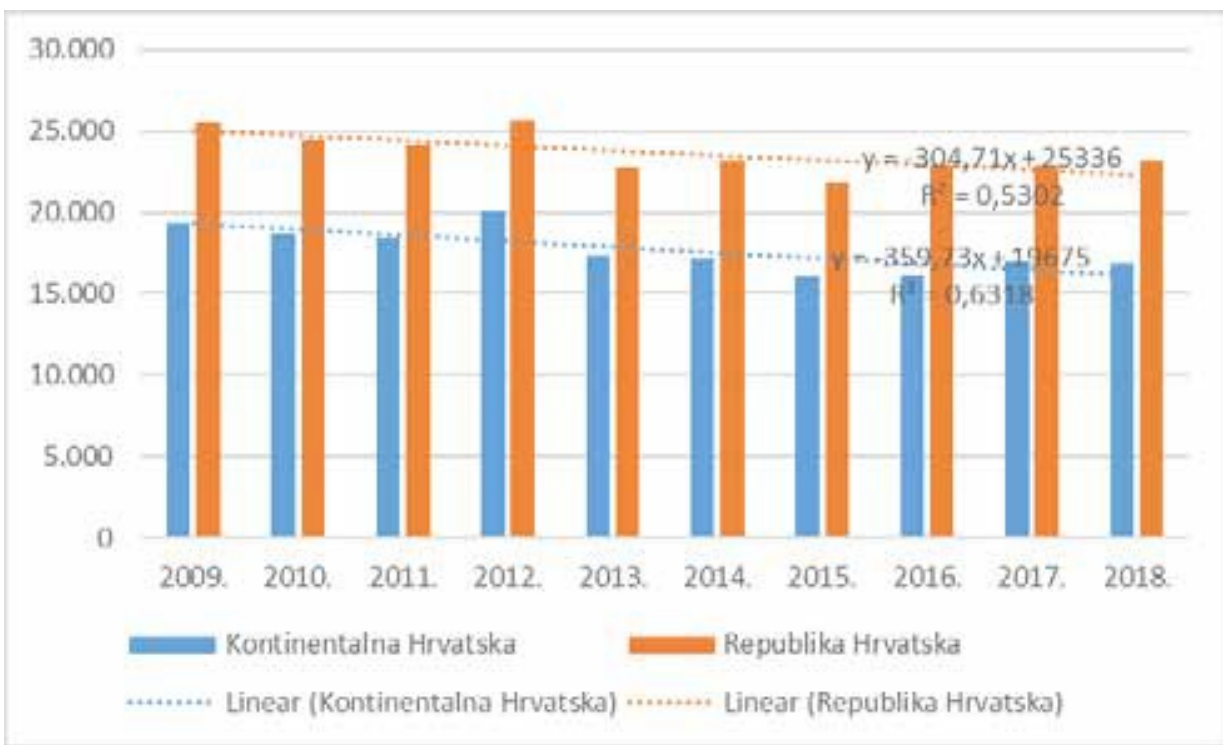

Grafikon 3. Brojzaposlenih u poljoprivredi u Republici Hrvatskoji Kontinentalnoj Hrvatskoj u razdoblju 2009. - 2018. godine

Graph 3. Number of employees in agriculture in the Republic of Croatia and in the Continental Croatia in the period 2009- 2018

Izvor: DZS, 2019e (obrada autora)/ Source: CBS, 2019e (Authors calculation)

Tablica 1. Prikaz izvoza i uvoza u poljoprivredi, šumarstvu i ribarstvu ${ }^{4}$ za Kontinentalnu $\mathrm{Hr}$ vatsku i Republiku Hrvatsku u tis. kn u razdoblju 2013. - 2018. godine

Table 1. Exports and imports in agriculture, forestry and fisheries for Continental Croatia and the Republic of Croatia in thousands of HRK in the period 2013 - 2018

\begin{tabular}{ccccccc}
\hline & \multicolumn{2}{c}{ Republika Hrvatska/ Republic of Croatia } & \multicolumn{2}{c}{ Kontinentalna Hrvatska/ Continental Croatia } \\
\hline $\begin{array}{c}\text { Godina/ } \\
\text { year }\end{array}$ & $\begin{array}{c}\text { Izvoz/ Export } \\
\text { (tis. kn) }\end{array}$ & $\begin{array}{c}\text { Uvoz/ } \\
\text { Import }\end{array}$ & $\begin{array}{c}\text { Pokrivenost } \\
\text { uvoza izvozom } \\
\text { (\%)/Coverage } \\
\text { of imports by } \\
\text { exports }\end{array}$ & $\begin{array}{c}\text { Izvoz/ Export } \\
\text { (tis. kn.) }\end{array}$ & $\begin{array}{c}\text { Uvoz/ } \\
\text { Import }\end{array}$ & $\begin{array}{c}\text { Pvoza izvozom } \\
\text { (\%)/Coverage } \\
\text { of imports by } \\
\text { exports }\end{array}$ \\
\hline 2013. & 1.394 .333 & 1.387 .692 & 100,5 & 924.195 & 1.069 .352 & 86,4 \\
\hline 2014. & 1.758 .774 & 1.427 .710 & 123,2 & 1.244 .185 & 1.038 .480 & 120,1 \\
\hline 2015. & 1.862 .196 & 1.484 .643 & 125,4 & 1.135 .077 & 1.065 .954 & 106,4 \\
\hline 2016. & 2.153 .623 & 1.852 .322 & 116,3 & 1.376 .940 & 1.333 .041 & 103,3 \\
\hline 2017. & 2.569 .490 & 2.123 .893 & 120,9 & 1.727 .735 & 1.533 .409 & 112,7 \\
\hline 2018. & 2.780 .573 & 2.460 .745 & 112,9 & 2.260 .855 & 1.758 .678 & 128,6 \\
\hline
\end{tabular}

Izvor: DZS, 2019c (obrada autora)/ Source: CBS, 2019c (Authors calculation) 


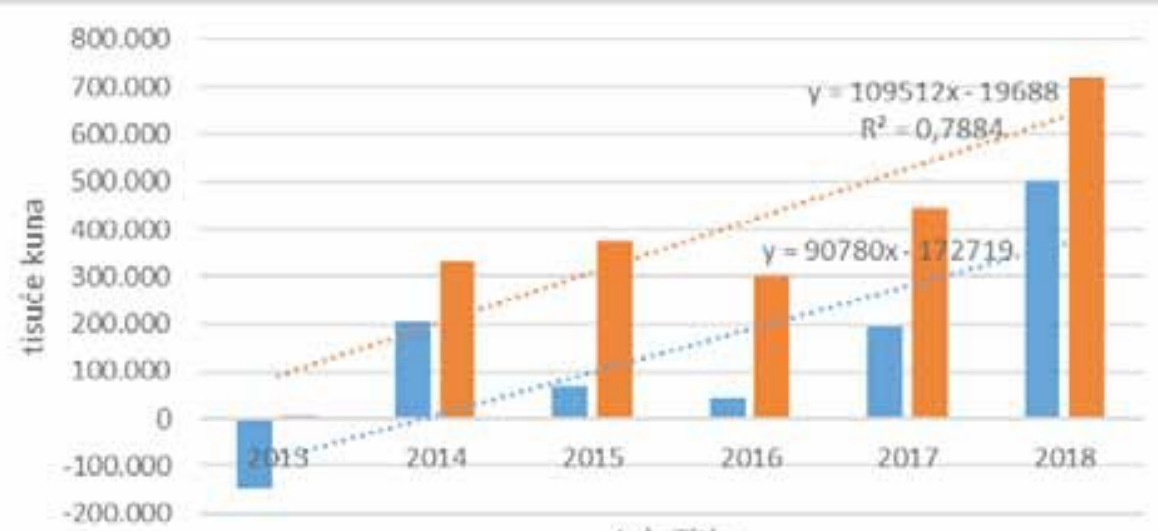

Axis Title

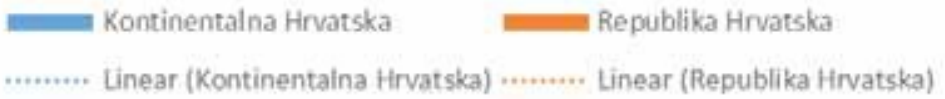

Grafikon 4. Vanjskotrgovinska bilanca poljoprivrede, šumarstva i ribarstva Republike Hrvatske i Kontinentalne Hrvatske u razdoblju od 2013. do 2018. godine

Graph 4. Foreign Trade Balance of Agriculture, Forestry and Fisheries of the Republic of Croatia and Continental Croatia from 2013 to 2018.

Izvor: DZS, 2019c (obrada autora)/ Source: CBS, 2019c (Authors calculation)

Izračun baznih indeksa pokazuje stalni porast izvoza Kontinentalne Hrvatske te je on 2018. godine oko 2,5 puta veći nego 2013. Pad uvoza zabilježen je 2014. i 2015. godine, nakon čega slijedi konstantan rast (tablica 2). On je sporiji od rasta izvoza što dovodi do pozitivne vanjskotrgovinske bilance u ovom sektoru. Situacija je jednaka i na državnoj razini.

Tablica 2. Bazni indeksi uvoza i izvoza u sektoru poljoprivrede, šumarstva i ribarstva za Republiku Hrvatsku i Kontinentalnu Hrvatsku u razdoblju od 2013. do 2018. godine

Table 2. Basic indices of imports and exports in the sector of Agriculture, Forestry and Fisheries for the Republic of Croatia and the Continental Croatia in the period from 2013 to 2018

\begin{tabular}{|c|c|c|c|c|}
\hline & \multicolumn{2}{|c|}{ Kontinentalna Hrvatska/ Continental Croatia } & \multicolumn{2}{|c|}{ Republika Hrvatska/ Republic of Croatia } \\
\hline & Izvoz/ export & Uvoz/ import & Izvoz/ export & Uvoz/ import \\
\hline 2013 & 100 & 100 & 100 & 100 \\
\hline 2014 & 126,14 & 97,11 & 126,14 & 102,88 \\
\hline 2015 & 122,82 & 99,68 & 133,55 & 106,99 \\
\hline 2016 & 148,99 & 124,66 & 154,46 & 133,51 \\
\hline 2017 & 186,94 & 143,40 & 184,28 & 153,05 \\
\hline 2018 & 244,63 & 164,46 & 228,11 & 177,33 \\
\hline
\end{tabular}

Izvor: Izračun autora prema podatcima DZS-a/ Source: Author's calculation according to CBS data 
Unatoč milijardama kuna godišnjih subvencija poljoprivredi bruto dodana vrijednost ${ }^{5}$ tog sektora konstantno pada, a tek je 2016. pad usporio (na 0,5\% nominalno i 0,1\% realno) i time bio manji uteg rastu BDP-a, nagovještavajući da bi ove godine napokon i poljoprivreda mogla ostvariti pozitivan rezultat (Dozan, 2017). BDV je na državnoj razini u 2017. godini unatoč očekivanjima pao za 0,46 \% u odnosu na 2016. godinu, no u Kontinentalnoj Hrvatskoj je u istom razdoblju porastao za 0,92 \% (grafikon 5). Većina bruto dodane vrijednosti poljoprivrede $\mathrm{RH}$ ostvari se u regiji Kontinentalne Hrvatske (83,93\% u 2017. godini).

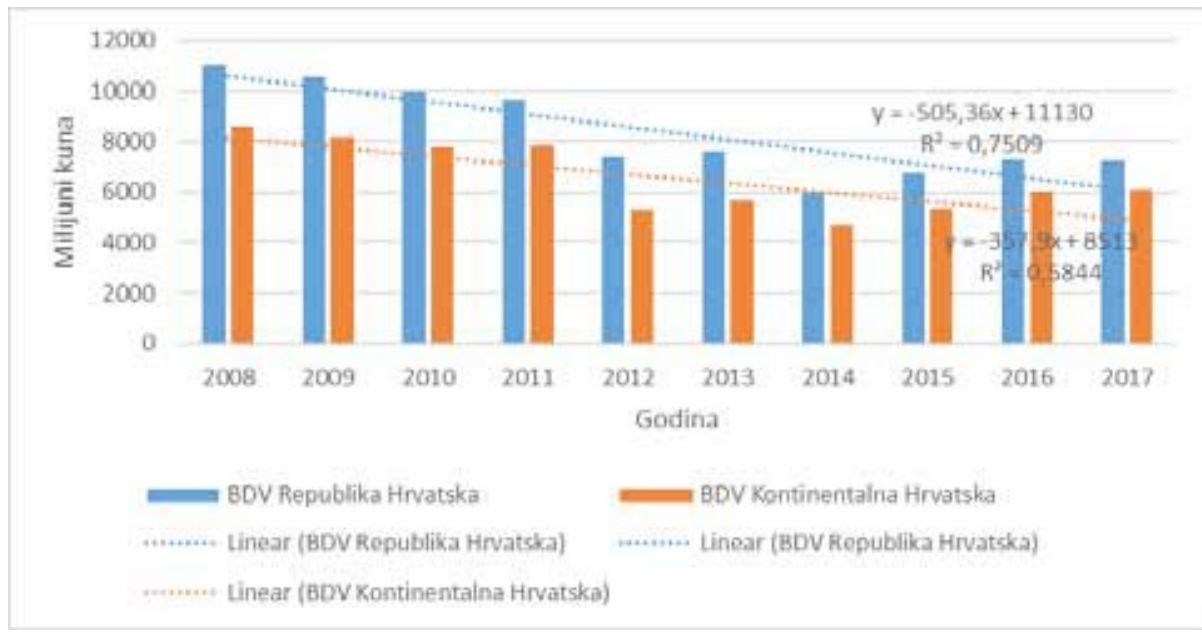

Grafikon 5. Bruto dodana vrijednost poljoprivrede u Republici Hrvatskoj i u Kontinentalnoj Hrvatskoj u razdoblju od 2008. do 2017. godine.

Graph 5. Gross value added of agriculture in the Republic of Croatia and in the Continental Croatia from 2008 to 2017.

Izvor: DZS, 2019b (obrada autora)/ Source: CBS, 2019b (Authors calculation)

\section{Proizvodna obilježja}

U 2017. godini evidentirano je 1.496 .663 ha korištenih poljoprivrednih površina u RH. Većina tih površina nalazi se na području Kontinentalne Hrvatske $(69,48 \%)$. U tablici 3 podatci prikazuju povećanje korištenih poljoprivrednih površina u razdoblju od 2007. do 2017. godine i to na razini $\mathrm{RH}$ za 52,92 \%, dok je u Kontinentalnoj Hrvatskoj taj rast iznosio 20,37 \%.

Tablica 3. Korištena poljoprivredna površina (ha) u razdoblju od 2007. do 2016. godine Table 3. Utilized agricultural area (ha) in the period 2007-2016

\begin{tabular}{cccccc}
\hline Godina/Year & 2007. & 2010. & 2013. & 2016. & 2017. \\
\hline Hrvatska/Croatia & 978.670 & 1.346 .340 & 1.571 .200 & 1.562 .980 & 1.496 .663 \\
\hline $\begin{array}{c}\text { Kontinentalna Hrvatska/ } \\
\text { Continental Croatia }\end{array}$ & 863.960 & 1.111 .340 & 1.103 .790 & 1.095 .430 & 1.039 .922 \\
\hline
\end{tabular}

Izvor: DZS, 2018/ Source: CBS, 2018

Većinu korištenih poljoprivrednih površina zauzimaju oranice, no zanimljivo je primijetiti da površine pod njima u promatranom razdoblju padaju unatoč povećanju ukupnih korištenih po- 
ljoprivrednih površina. Rast je zabilježen samo u kategoriji trajnih travnjaka što je prema Mikuš i sur. (2019) pozitivno za okoliš, no negativno za ostvarivanje dodatne vrijednosti u hrvatskoj poljoprivredi što je prikazano i u grafi

5.

Tablica 4. Prikaz biljne proizvodnje u Kontinentalnoj Hrvatskoj u razdoblju od 2009. do 2018.

Table 4. Overview of plant production in Continental Croatia from 2009 to 2018.

\begin{tabular}{ccccc}
\hline & $\begin{array}{c}\text { Oranice i vrtovi/ } \\
\text { Arable land }\end{array}$ & $\begin{array}{c}\text { Trajni travnjaci/ } \\
\text { Permanent grassland }\end{array}$ & $\begin{array}{c}\text { Trajni nasadi/ } \\
\text { Permanent crops }\end{array}$ & $\begin{array}{c}\text { Povrtnjaci/ vegetable } \\
\text { gardens }\end{array}$ \\
\hline 2009. & 826.547 & 201.960 & 52.719 & 4.536 \\
\hline 2010. & 860.756 & 202.389 & 44.254 & 3.758 \\
\hline 2011. & 855.232 & 196.927 & 42.810 & 3.126 \\
\hline 2012. & 867.075 & 196.222 & 39.463 & 2.180 \\
\hline 2013. & 842.457 & 200.916 & 37.841 & 1.721 \\
\hline 2014. & 776.429 & 219.590 & 40.576 & 1.653 \\
\hline 2015. & 809.279 & 219.590 & 37.921 & 1.653 \\
\hline 2016. & 837.821 & 219.590 & 36.785 & 1.305 \\
\hline 2017. & 786.987 & 215.185 & 36.202 & 1.548 \\
\hline 2018. & 774.543 & 215.185 & 38.556 & 1.548 \\
\hline
\end{tabular}

Izvor: DZS, 2019a./ Source: CBS, 2019a

Istraživanje Grgića i sur. (2019) je pokazalo da u strukturi ukupne hrvatske poljoprivredne proizvodnje dominira biljna proizvodnja (oko $65 \%$ ) u odnosu na stočarsku (oko 35 \%). Situacija je vrlo slična i u strukturi poljoprivrednog outputa $\mathrm{RH}$, gdje output biljne proizvodnje u 2017. čini $58,38 \%$, a output stočarske proizvodnje 37,20 \%, a u Kontinentalnoj Hrvatskoj, 56,67\% naspram $38,42 \%$. Preostali udio u poljoprivrednom outputu čini output poljoprivrednih usluga. Trend outputa stočarske i biljne proizvodnje je u Kontinentalnoj Hrvatskoj, kao i na razini cijele Hrvatske negativan (grafi 6).

U tablici 5 je prikazan broj goveda, svinja i ovaca u Kontinentalnoj Hrvatskoj kao i na razini cijele države. U 2018. godini imamo manje goveda i svinja, a više ovaca u odnosu na 2009. godinu. Kao što navode Grgić i sur. (2019.) smanjenje govedarstva i svinjogojstva zabrinjavaju jer su to često pokazatelji stanja poljoprivrednog sektora.

Tablica 5. Prikaz životinjske proizvodnje (broj grla) u Kontinentalnoj Hrvatskoj i Republici Hrvatskoj u razdoblju od 2009. - 2018. godine

Table 5. Animal production (number of heads) in Continental Croatia and in the Republic of Croatia in the period 2009-2018

\begin{tabular}{ccccccc}
\hline & \multicolumn{2}{c}{ Kontinentalna Hrvatska/ Continental Croatia } & \multicolumn{3}{c}{ Republika Hrvatska/ Republic of Croatia } \\
\hline & Goveda/ Cattle & Svinje/ Pigs & Ovce/ sheeps & Goveda/ Cattle & Svinje/ Pigs & Ovce/ sheeps \\
\hline 2009. & 406.784 & 1.232 .495 & 279.628 & 447.151 & 1.249 .874 & 619.044 \\
\hline 2010. & 411.929 & 1.205 .481 & 299.720 & 444.314 & 1.230 .574 & 629.437 \\
\hline 2011. & 402.706 & 1.072 .543 & 317.932 & 446.555 & 1.233 .406 & 638.608 \\
\hline 2012. & 411.848 & 1.061 .853 & 325.521 & 451.517 & 1.182 .347 & 679.313 \\
\hline 2013. & 407.875 & 1.092 .704 & 280.540 & 442.432 & 1.110 .650 & 619.852 \\
\hline 2014. & 408.832 & 1.137 .125 & 262.960 & 440.637 & 1.156 .220 & 604.866 \\
\hline 2015. & 406.905 & 1.143 .289 & 280.096 & 440.092 & 1.166 .888 & 607.711 \\
\hline 2016. & 407.472 & 1.143 .951 & 240.608 & 444.613 & 1.163 .027 & 618.896 \\
\hline 2017. & 404.029 & 1.104 .699 & 254.043 & 450.757 & 1.121 .032 & 636.808 \\
\hline 2018. & 369.635 & 1.049 .123 & 308.641 & 414.125 & 1.035 .015 & 636.294 \\
\hline
\end{tabular}

Izvor: DZS, 2019d./ Source: CBS, 2019d 


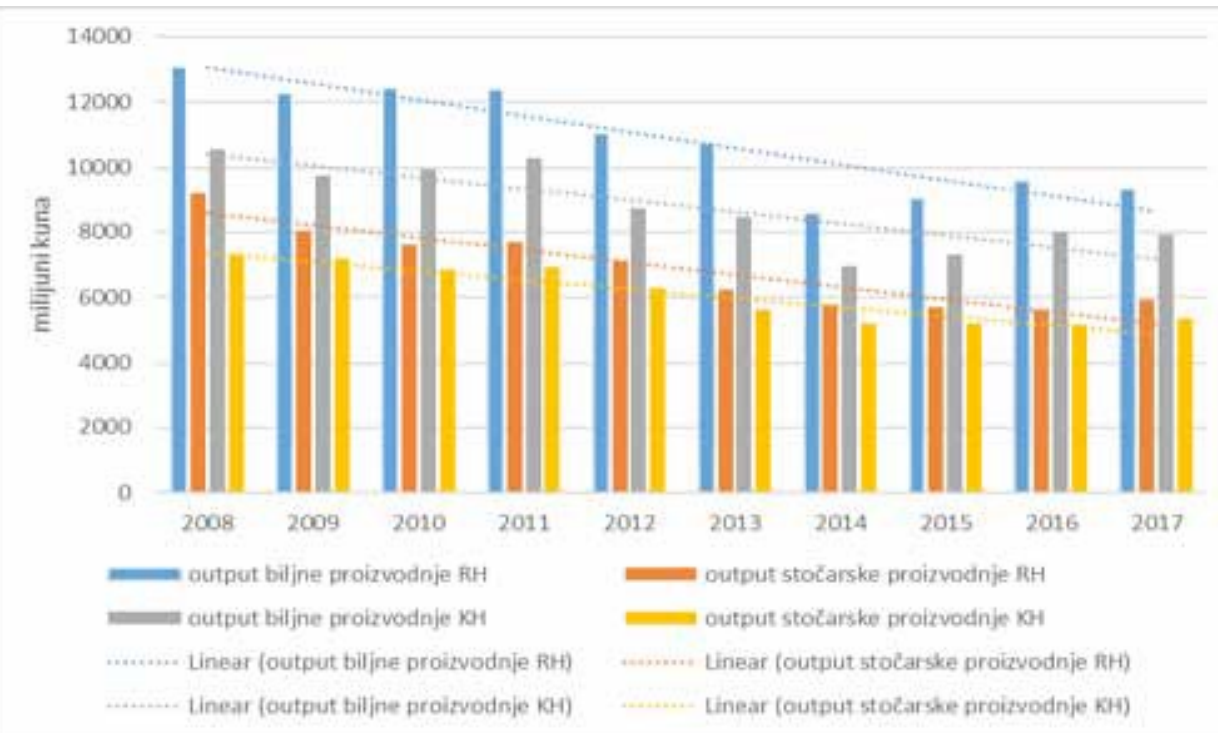

Grafikon 6. Output biljne i stočarske proizvodnje u Republici Hrvatskoj i Kontinentalnoj Hrvatskoj

Graph 6. Output of crop and livestock production in the Republic of Croatia and ContinentalCroatia

Izvor: DZS, 2019b./ Source: CBS, 2019b

\section{Zaključak}

Obilježja poljoprivredne proizvodnje u Kontinentalnoj Hrvatskoj po svojoj vrijednosti ne razlikuju se znatno od istih na državnoj razini. Dobna struktura nositelja OPG-ova je nešto povoljnija u Kontinentalnoj Hrvatskoj (veći udio mlađih od 41 godine - 13,27\%; manji udio starijih od 65 godina - 35,67\% dok je obrazovna lošija (koeficijent obrazovanosti 1,38). Broj zaposlenih u poljoprivredi je u padu, dok vanjskotrgovinska razmjena poljoprivrede, šumarstva i ribarstva bilježi rast vrijednosti u promatranom razdoblju kako u Kontinentalnoj Hrvatskoj tako i na razini cijele države.

Povećanje korištenih poljoprivrednih površina posljedica je rasta površina pod trajnim travnjacima što je dobro za okoliš, ali loše za bruto dodanu vrijednost poljoprivrede koja ima negativan trend u promatranom razdoblju. Navedeno je i posljedica smanjenja stočarske proizvodnje, posebice govedarstva i svinjogojstva.

Hrvatskoj poljoprivredi potrebna je generacijska obnova koja će ujedno pridonijeti poboljšanju obrazovne strukture i veća usmjerenost sredstava u stočarsku proizvodnju koja stvara veću dodanu vrijednost.

\section{Napomena}

Ovaj rad je nastao iz završnog rada studenta Petra Glavote pod naslovom Regionalna obilježja poljoprivredne proizvodnje Kontinentalne Hrvatske obranjenog dana 5. rujna 2019. godine na Agronomskom fakultetu u Zagrebu pod mentorstvom dr.sc. Mateje Jež Rogelj. 


\title{
Literatura
}

Agencija za plaćanja u poljoprivredi, ribarstvu i ruralnom razvoju (2019) Upisnik poljoprivrednika - stanje na dan 31.12.2018. URL: https://www.apprrr.hr/upisnik-poljoprivrednika/ (15.11.2019.)

Augère-Granier, M. L. (2017). Agriculturaleducationand lifelongtrainingin the EU. URL: http://www.europarl.europa.eu/RegData/etudes/BRIE/2017/608788/EPRS_BRI(2017)608788_EN.pdf (20.1.2020.)

Dozan, J. (2017). Poljoprivreda i dalje utēg BDP-u, ostali se-ktori rasli. URL: http://www.poslovni.hr/hrvatska/poljoprivreda-i-dalje-uteg-bdp-u-ostali-sektori-rasli-325187. (21.11.2019.)

Državni zavod za statistiku (2019a) Biljna proizvodnja. URL: http://www.dzs.hr/PXWeb/sq/9c7403cc-d832-47d3b52c-89b901976edd (19.11.2019.)

Državni zavod za statistiku (2019b) Ekonomski računi u poljoprivredi. URL: http://www.dzs.hr/PXWeb/sq/ a92a04f6-99eb-40ff-b4d8-439c688d45ef (20.11.2019.)

Državni zavod za statistiku (2018) Poljoprivredna proizvodnja u 2017. URL: https://www.dzs.hr/Hrv_Eng/publication/2018/SI-1610.pdf. (29.11.2019.)

Državni zavod za statistiku (2019c) Robna razmjena s inozemstvom. URL: https://www.dzs.hr/Hrv_Eng/Pokazatelji/Robna razmjena s inozemstvom - pregled po zupanijama.xlsx (15.11.2019)

Državni zavod za statistiku (2019d) Stočarska proizvodnja. URL: http://www.dzs.hr/PXWeb/sq/2977c4f9-e16548d0-bf7d-f79f2a0e82b8 (18.11.2019.)

Državni zavod za statistiku (2019e) Zaposleni prema područjima djelatnosti i po županijama. URL: https://www. dzs.hr/Hrv_Eng/publication/2018/09-02-04_01_2018.htm (30.11.2019.)

Grgić, I., Krznar, S., Bratić, V. (2019) Poljoprivredna proizvodnja Republike Hrvatske prije i nakon pristupanja EU. U: Bilandžija, N., Kovačev, I., ur. Aktualni zadaci mehanizacije poljoprivrede. Zagreb: Sveučilište u Zagrebu, Agronomski fakultet, Zavod za mehanizaciju poljoprivrede, 487-496.

Jež Rogelj, M., Hadelan, L., Kovačićek, T., Mikuš, O. (2019) Obrazovanost kao preduvjet inovativne poljoprivrede. Agroeconomia Croatica, 9 (1), 81-90.

Mikuš, O., Ravlić, M., Hadelan, L., Jež Rogelj, M., Ljubaj, T. (2019) Uloga poljoprivredne politike u odnosu poljoprivrede i okoliša. U: Mioč, B, Širić, I., ur. Zbornik radova 54. hrvatskog i 14. međunarodnog simpozija agronoma. Zagreb: Agronomski fakultet Sveučilišta u Zagrebu, 143-147.

Stipić, S. (2018.). Stavovi i mišljenja mladih o prednostima i nedostatcima življenja na selu. Sveučilište u Zagrebu Agronomski fakultet, Diplomski rad.

Prispjelo/Received: 2.12.2019.

Prihvaćeno/Accepted: 11.2.2020.

\section{Regional characteristics of agricultural production in Continental Croatia}

\begin{abstract}
The aim of the paper was to determine selected economic and production indicators of the agricultural development in Continental Croatia from 2009 to 2018. The age structure of the family farm holders is more favorable in Continental Croatia (a higher proportion of those under theage of 41; a lower proportion of those over the age of 65) in relation to the national average, while the education is lower (education coefficient 1.38). The number of employees in agriculture is declining, while the foreign trade of agriculture, forestry and fisheries recorded an increase in value in the observed period. The utilized agricultural area increased in the observed period solely due to the increase in the area under permanent grassland, which had a negative impact on the gross value added of agriculture, which has a negative trend in the observed period. Previously mentioned is also a consequence of the decline in livestock production, in particular cattle and pig production. Croatian agriculture needs a generational renewal that will at the same time contribute to improving the educational structure and also a greater focus on livestock production that creates greateradded value.
\end{abstract}

Keywords: agriculture, Continental Croatia, production indicators, $\mathrm{RH}$, socio-economic characteristics 